\title{
AUREOMYCIN BORATE IN EXTERNAL OCULAR CONDITIONS*
}

BY

\author{
R. J. McWILLIAM AND T. WILSON \\ Eye Department, Western Infirmary, Glasgow
}

IN seventeen cases of external ocular conditions treated with aureomycin borate, only eye drops were used, and in no case was the substance given orally. All were admitted to hospital and their conditions estimated daily by a numerical code. Routine bacteriological examinations were carried out, any organisms found being tested for sensitivity to penicillin and aureomycin.

Since it was first described by Duggar (1948), aureomycin has been used successfully in an impressively large number of infections. It has been reported to be of value in many ocular conditions, used both locally and orally, but a critical assessment cannot be made as it has not been sufficiently widely used.

Aureomycin is usually prescribed as the hydrochloride salt for oral use; this preparation is suitable for intra muscular injection although it is sometimes irritant, and it has also been used intravenously without untoward effect. The hydrochloride salt, however, is too irritant to be used locally in the conjunctival sac; for this purpose a borate salt in 0.5 per cent. solution, or aureomycin ethylene diamine in 1.25 per cent. solution, have been employed. According to Bellows, Richardson, and Farmer (1950) these concentrations do not injure healthy corneal epithelium nor do they delay epithelial healing when used three- or four-hourly, although half-hourly administration is certainly inadvisable. The manufacturers $\$$, however, state that aureomycin ethylene diamine locally applied may irritate the eye; it is therefore probable that aureomycin borate is the most suitable preparation for local application to the eye. It is supplied in the form of a powder containing:

\begin{tabular}{|c|c|}
\hline Aureomycin hydrochloride & $25 \mathrm{mg}$. \\
\hline $\begin{array}{l}\text { Sodium borate } \\
\text { Sodium chloride }\end{array}$ & $\begin{array}{l}-25 \mathrm{mg} . \\
-625 \mathrm{mg}\end{array}$ \\
\hline
\end{tabular}

To this powder is added $5 \mathrm{ml}$. distilled sterile water to make a 0.5 per cent. solution in saline, with a $p \mathrm{H}$ between 7.5 and 7.8. The antibiotic maintains its activity in this form for 48 hours, after which the solution should be discarded. Aureomycin ethylene diamine is not yet available in Great Britain.

- Received for publication December 27, 1950.

+ Messrs. Lederle Laboratories Division, American Cyanide Co. 


\section{Method}

All patients treated were admitted to hospital in order to control the administration and to make the extraneous environment as uniform and satisfactory as possible. Treatment was given every two hours, night and day, for three days, into both eyes, whether or not the second eye was affected. This was followed by saline drops two-hourly for a similar period. Cultures from both conjunctival sacs were taken before the aureomycin treatment was begun and after the saline course. The patient's clinical condition was estimated daily on a numerical code.

In no case was aureomycin given systemically and all other forms of chemotherapy were stopped during the course of treatment, except in one case of orbital cellulitis. Consequently, in uniocular cases, the second eye was protected with aureomycin. Each patient was given a three-day course of aureomycin borate, approximately 60 to $75 \mathrm{mg}$. being used in each case. If cure was not obtained, but there were some signs of improvement, a further course was given. Most patients, however, received only one course of this intensive therapy. The number of courses which each patient received is indicated in Table $I$.

TABLE I

DETAILS OF INVESTIGATION

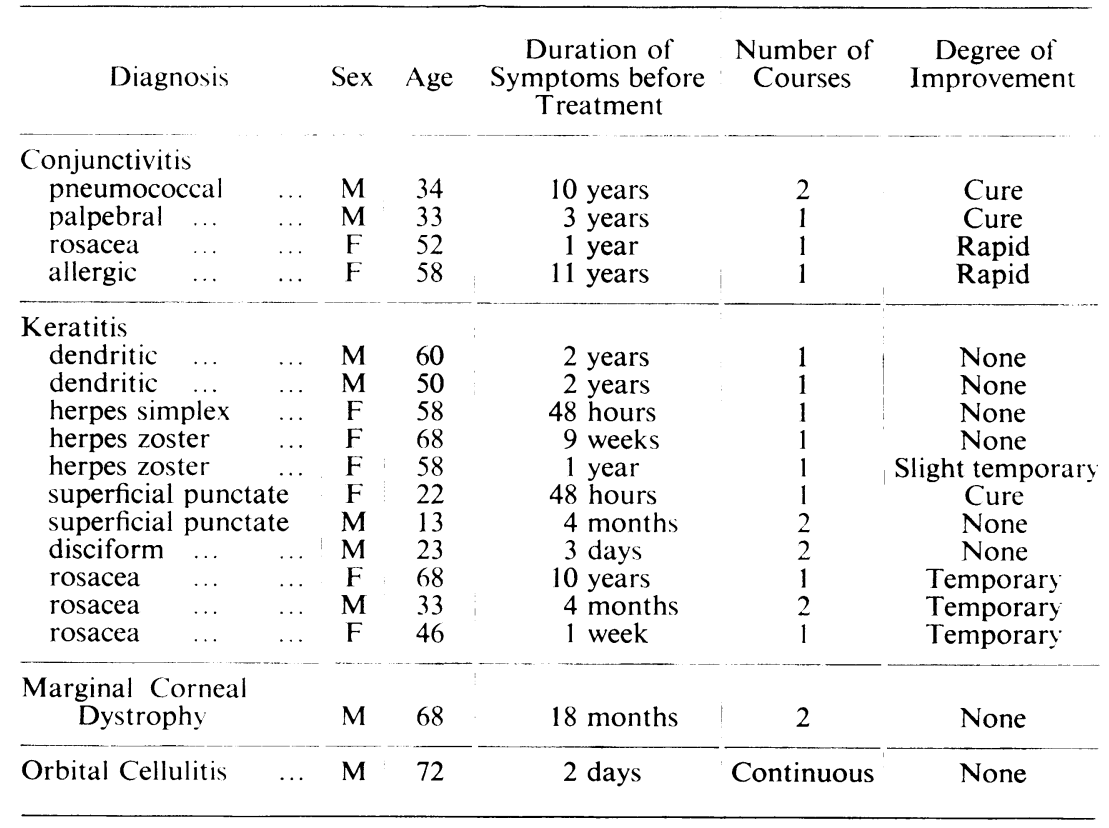

Material

Seventeen cases of assorted eye conditions, mainly chronic and unresponsive to routine methods of therapy, were chosen and admitted to hospital (Table I). Each case was deliberately chosen with this in mind, and there was no random selection. It is considered that the aureomycin was given a very severe trial and if it had succeeded in clearing up the cases to which it was given, it would indeed have been an extremely potent therapeutic agent. 


\section{Conjunctivitis}

\section{RESULTS}

(i) Recurrent pneumococcal conjunctivitis in a man aged 34 was treated with dramatic result. The condition had recurred over a period of 10 years and had not responded to the usual treatments, although the organisms were still penicillin-sensitive. Both tear sacs were patent, and $x$-ray of sinuses and chest were within normal; examination by a general physician and an E.N.T. surgeon did not reveal any abnormality. Routine blood examinations, haemoglobin, red- and white-cell counts, and blood films were normal, and the Wassermann reaction was negative. Culture showed a heavy, almost pure growth of pneumococci. The condition resolved rapidly after aureomycin and the second and all subsequent cultures were negative for pneumococci. Some slight conjunctival injection persisted after the end of the first course of aureomycin; this rapidly cleared when a second course of treatment was given.

(ii) Chronic palpebral conjunctivitis of uncertain aetiology in a man of 33, whose symptoms had persisted off and on for 3 years, showed great improvement with aureomycin.

(iii) Rosacea keratitis which had been troubling the patient for a year, improved rapidly with aureomycin.

(iv) Allergic conjunctivitis of uncertain aetiology, present off and on for 11 years, improved rapidly with aureomycin. This improvement was more rapid than had occurred in any previous exacerbation; when seen two months later the eyes were quiet, but four months later there was a slight recurrence in one eye.

Keratitis.-Because of the known efficacy of aureomycin in virus diseases such as atypical pneumonia, psittacosis, dermatitis herpetiformis, and herpes zoster of the skin, it was hoped that there would be a similar good response in virus and virus-like diseases of the cornea. In our material, however, this hope was not fulfilled.

(i) Dendritic ulcer. Two cases showed no improvement.

(ii) Herpes febrilis corneae in a school-teacher who had been in contact with cases of chicken-pox in her class. In spite of almost immediate use of aureomycin, treatment having been commenced within 48 hours of the onset of symptoms, the lesion pursued a chronic course over several weeks.

In contrast to our results, Zeller and O'Conner (1950) report improvement in all seven cases of dendritic ulcer treated, complete healing resulting in from 4 to 21 days. In all their cases, except the last, treatment was begun within 3 days of the onset of the symptoms. Thygeson and Hogan (1950) state that aureomycin may be expected to cure some 60 per cent. of cas es of herpes simplex cornea. These authors treated 
24 such cases and found improvement in fourteen. In the only large series of cases reported (401 in all), Braley and Sanders (1949) treated 21 cases of dendritic ulcer with improvement in thirteen. Ainslie (1950) treated nine cases of dendritic ulcer. but, like us, obtained no improvement in any.

On the experimental side, Bellows, Richardson, and Farmer (1950) denuded the corneal epithelium of both eyes of eight rabbits and applied vaccinia for one minute. Immediately thereafter, aureomycin drops were instilled into the right eyes and continued thrice daily for 7 days, and the left eyes were treated similarly with saline. "Infections of equal intensity were noted bilaterally".

(iii) Superficial punctate keratitis. Two cases were treated, one of which showed improvement, cure resulting in 4 days. This

TABLE II

DISTRIBUTION OF RESULTS

Presumed
Cause Cured Improved $\begin{gathered}\text { Not } \\ \text { Improved }\end{gathered}$

\begin{tabular}{lcccc} 
Bacterial $\ldots$ & 4 & 0 & 1 \\
\hline Systemic $^{*}$ & $\ldots$ & 0 & 3 & 1 \\
\hline Virus & $\ldots$ & 1 & 1 & 6
\end{tabular}

* Improvement in the systemic group may be due to control patient was aged 22 years and treatment was begun within 48 hours of the onset of the symptoms. In the other patient, a boy of 13 years, symptoms had been present for 4 months before aureomycin was given, and nodramatic improvement was obtained, even after a second course, though slow improvement occurred in the

two weeks following the second course of aureomycin.

(iv) Disciform keratitis. In the one case treated slow improvement occurred in the 3 weeks following two courses of aureomycin. but 3 months later there were still some persistent symptoms, and it is doubtful if the substance exerted any great influence on the condition.

(1) Herpes zoster. Two cases were treated, with some slight improvement in one, which relapsed when treatment was stopped. In the other, there was an associated iridocyclitis, and neither this nor the corneal lesions showed any improvement.

(vi) Rosacea keratitis. Three cases improved during treatment, but all subsequently relapsed. The benefit might have been due to the control of secondary infection.

These findings may be compared with those of Braley and Sanders, who treated six cases of rosacea keratitis, with improvement in only one. In none of our cases was there any permanent benefit.

Marginal Corneal Dystrophy.-One case with ulceration showed no improvement.

Orhital Cellulitis.-One case with sloughing of skin was treated 
with local aureomycin dressings as well as systemic penicillin. The condition resolved in about 3 weeks, the aureomycin having apparently had no effect.

A summary of these results is given in Table II, and the bacteriological findings in Table III.

TABLE III

BACTERIOLOGICAL INVESTIGATIONS

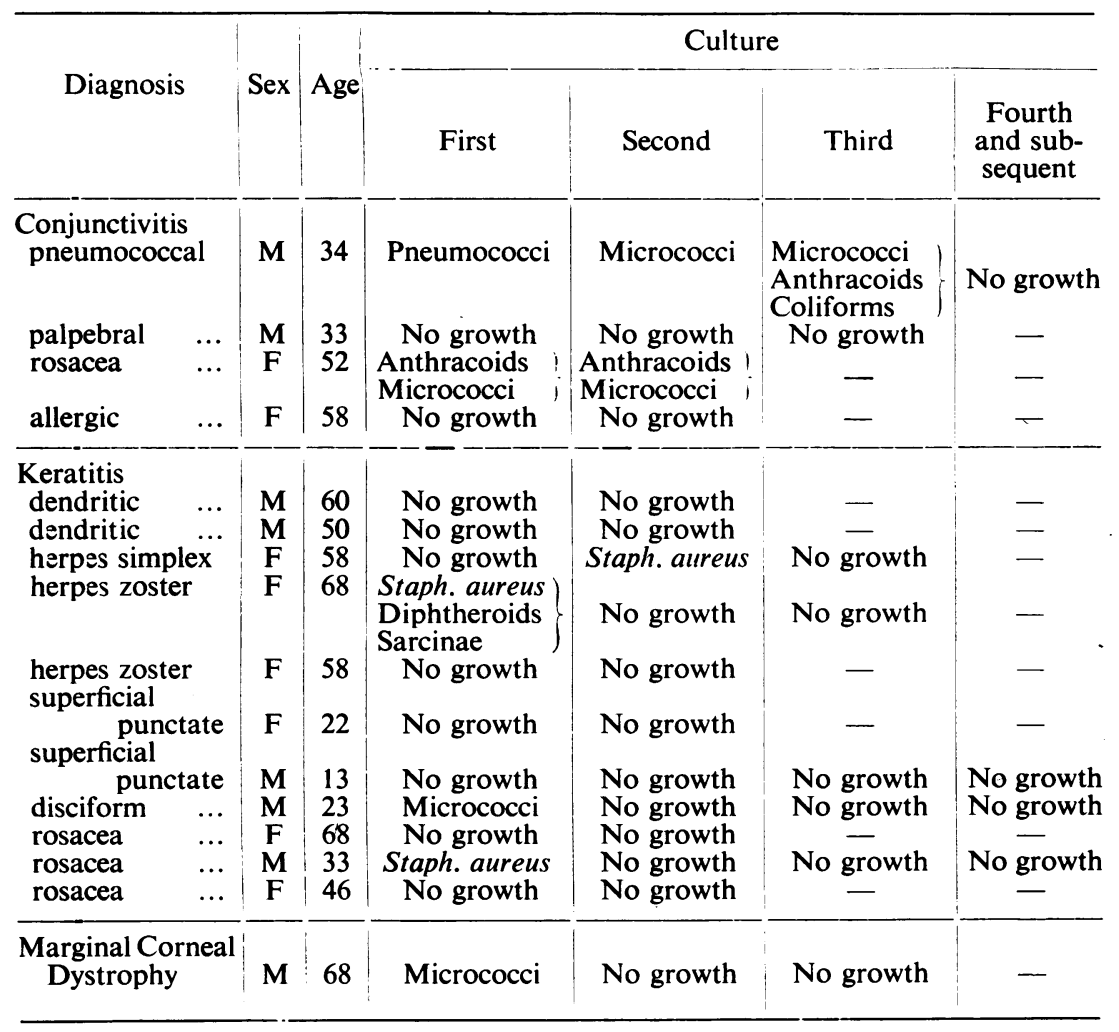

\section{TOXIC EFFECTS}

No serious toxic effects were noted in any of our patients treated with local aureomycin, though some complained of smarting when the drops were instilled. Indeed, in one or two persons, a slight increase in conjunctival injection was observed, so that the daily clinical assessments had to be made shortly before the insertion of the drops, that is, about one and a half hours after the previous drops. We did not observe any swelling of the eyelids, pruritus, or urticaria uluchare mentioned by Burstein (1950), and in none of our rosacea cases was the pre-existing acne made worse. 


\section{DISCUSSION}

Analysis of our results does not indicate any great therapeutic advantage in the routine use of aureomycin borate eyedrops over the more usual, less expensive, and more readily available remedies. We have not had the opportunity of testing the substance against an established penicillin-resistant strain of organisms in which case aureomycin might prove to be invaluable. All the patients with conjunctivitis had failed to respond satisfactorily to penicillin, although the identified organisms were said to be penicillin sensitive.

Comparison of our results with other published series of cases (Table IV) show that they are, by and large, similar, except in the case of virus conditions, where we were unable to substantiate the good results obtained by American workers (Our series shows 2 cases improved out of 8, as against Braley and Sanders' 15 cases improved out of 29). It does not appear, however, that local aureomycin borate has the same beneficial result in virus diseases of the cornea as oral aureomycin hydrochloride appears to have in generalized virus diseases.

TABLE IV

COMPARATIVE RESULTS

\begin{tabular}{|c|c|c|c|c|c|c|c|c|c|}
\hline \multirow{2}{*}{ Diagnosis } & \multicolumn{3}{|c|}{ Present Series } & \multicolumn{3}{|c|}{ Ainslie (1950) } & \multicolumn{3}{|c|}{$\begin{array}{c}\text { Braley and Sanders } \\
(1949)\end{array}$} \\
\hline & Total & $\begin{array}{l}\text { Im- } \\
\text { proved }\end{array}$ & $\begin{array}{l}\text { Not im- } \\
\text { proved }\end{array}$ & Total & $\begin{array}{c}\text { Im- } \\
\text { proved }\end{array}$ & $\begin{array}{l}\text { Not im- } \\
\text { proved }\end{array}$ & Total & $\begin{array}{c}\mathrm{Im}^{-} \\
\text {proved }\end{array}$ & $\begin{array}{l}\text { Not im- } \\
\text { proved }\end{array}$ \\
\hline 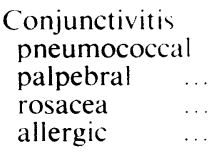 & $\begin{array}{l}1 \\
1 \\
1 \\
1\end{array}$ & $\begin{array}{l}1 \\
1 \\
1\end{array}$ & $\begin{array}{l}0 \\
0 \\
0 \\
0\end{array}$ & $\begin{array}{l}0 \\
0 \\
0 \\
0\end{array}$ & $\begin{array}{l}0 \\
0 \\
0 \\
0\end{array}$ & $\begin{array}{l}0 \\
0 \\
0 \\
0\end{array}$ & $\begin{array}{r}10 \\
312\end{array}$ & $\begin{array}{r}10 \\
278\end{array}$ & $\begin{array}{r}0 \\
54\end{array}$ \\
\hline $\begin{array}{l}\text { Keratitis } \\
\text { dendritic } \\
\text { herpes simplex } \\
\text { herpes zoster } \\
\text { superficial } \\
\text { punctate } \\
\text { disciform } \quad . . \\
\text { rosacea }\end{array}$ & $\begin{array}{l}2 \\
1 \\
3\end{array}$ & $\begin{array}{l}1 \\
0 \\
3\end{array}$ & $\begin{array}{l}1 \\
1 \\
0\end{array}$ & $\begin{array}{r}5 \\
2 \\
\end{array}$ & $\begin{array}{l}2 \\
2\end{array}$ & $\begin{array}{l}3 \\
0\end{array}$ & $\frac{7}{6}$ & $\begin{array}{r}\frac{13}{0} \\
\frac{2}{1}\end{array}$ & $\begin{array}{c}\frac{8}{1} \\
\frac{5}{5} \\
\frac{5}{5}\end{array}$ \\
\hline $\begin{array}{c}\text { Marginal Corneal } \\
\text { Dystrophy }\end{array}$ & 1 & 0 & 1 & -- & & - & 2 & 0 & 2 \\
\hline Orbital Cellulitis & 1 & 0 & 1 & 一 & - & - & - & - & - \\
\hline
\end{tabular}

* Cases cured and improved added together

It is again emphasized that in our series of cases, preference was given to chronic and resistant lesions, against which the usual 
remedies had failed. It is possible also, that courses of longer duration than 3 days might have increased our number of successes, but it was usually possible to decide whether there had been any beneficial effect in this time.

\section{SUMMARY}

(1) Seventeen cases of ocular lesions treated with local aureomycin borate, with bacteriological control, are reported.

(2) It had been hoped, in particular, that virus diseases of the cornea would have responded, but in our experience this has not been so.

(3) Aureomycin does not appear to have any great advantage over the more usual forms of therapy in cases of keratitis. In four cases of chronic and resistant conjunctivitis, however, rapid improvement resulted.

(4) The substance may be of use for penicillin-resistant organisms and in cases of chronic conjunctivitis not responding to other forms of therapy.

(5) Our conclusions agree with those of Duke-Elder, Ainslie, and Boase (1950), who found that in the various infections commonly found in Great Britain, the results with aureomycin were not dramatic.

We should like to thank Dr. I. R. W. Lominski for the bacteriological examinations and for advice on this aspect of the work. Our thanks are also due to other members of the Western Infirmary staff for their help and to the nursing staff for carrying out the treatment. Our supplies of aureomycin borate were made available by the Department of Health for Scotland. We should also like to express our appreciation to Prof. W. J. B. Riddell, under whose general direction the inquiry was conducted.

\section{REFERENCES}

AINSLIE, D. (1950). British Journal of Ophthalmology, 34, 31.

Bellows, J. G., Richardson, V. M., and Farmer, C. J. (1950). Amer. J. Ophthal., 33, 273.

Braley, A. E., and Sanders, M. (1949). Ibid., 32, 119.

BURSTEIN, F. (1950). Ibid., 33, 973.

Duggar, B. M. (1948). Ann. N.Y. Acad. Sc., 51, 177.

Duke-Elder, S., AINSLIE, D., and BoASE, A. J. (1950). British Journal of Ophthalmology, $34,30$.

Thygeson, P., and Hogan, M. J. (1950). Amer. J. Ophthal., 33, 958.

Zeller, R. W., and O'Conner, E. F. (1950). Ibid., 33, 619. 